\title{
Looking back at Professor PhDr. Antonín Rychtecký, DrSc.
}

\author{
Pavel Slepička
}

\author{
Faculty of Physical Education and Sport, Charles University, Prague, Czech Republic \\ slepicka@ftvs.cuni.cz
}

DOI

10.14712/23366052.2021.2

With grief, all of us who knew our colleague Antonín Rychtecký and were able to work with him received the news of his death. He died on December 6, 2020 after a long illness at the age of 75 .

Antonín Rychtecký was born on 19. 9. 1945 in Vysoké Studnice in the district of Jihlava. After completing primary and secondary education, in accordance with his sporting interests, which also shaped his personality, he chose the Institute of Physical Education and Sport, the current Faculty of Physical Education and Sport, as the place of his university studies. This decision was, to a certain extent, a "fateful" decision, as he spent not only his student years at this faculty, but subsequently his entire professional career. The meeting with prof. Miroslav Vaněk, an internationally recognized representative of sport psychology, whose lectures on psychology and sport psychology aroused his interest in these fields. These subsequently played an important role in his further professional and vocational focus, as after graduating from the faculty he continued his scientific development within the internal postgraduate course, similar to current doctoral studies, as evidenced by his first research work focused on free effort in physical activity.

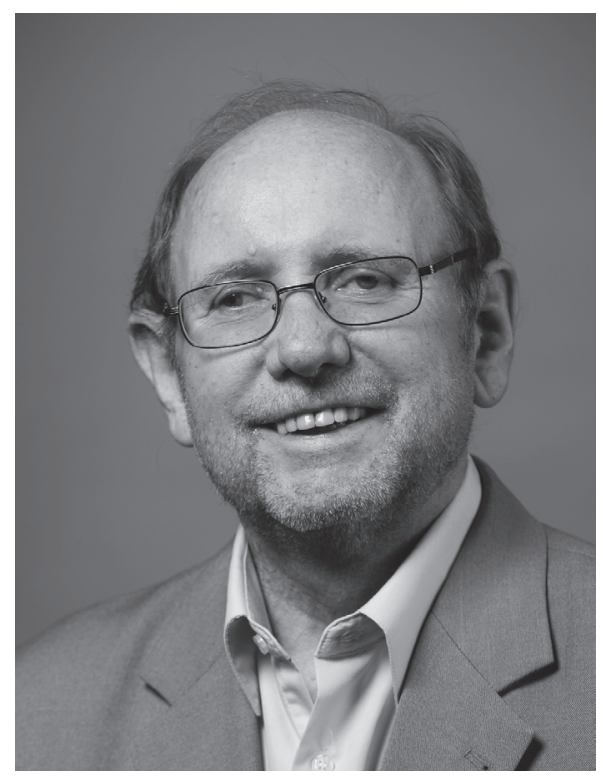

(c) 2021 The Author. This is an open-access article distributed under the terms of the Creative Commons Attribution License (http://creativecommons.org/licenses/by/4.0), which permits unrestricted use, distribution, and reproduction in any medium, provided the original author and source are credited. 
Subsequently, as a member of the constituted department of sport psychology FTVS, he significantly contributed to its development into an important workplace both in the faculty, national and international contexts. His pedagogical and scientific work showed a tendency to set high goals, diligence, the effort to achieve his goals. It can be said that he devoted a substantial part of his life to the faculty, he lived by the faculty, he worked for the faculty, always to the fullest.

In his pedagogical and scientific research work, he gradually and increasingly focused on the issue of psychological contexts, especially school physical education, where he was interested in issues of motor performance, the role of motivation in physical education and subsequently the issue of Olympism. His scientific contribution to this area is evidenced by numerous publications, both domestic and foreign, and includes, for example, the book "Didactics of School Physical Education" or "Lifestyle of the Youth Population", which also brings standards and norms of motor performance of youth that will influence physical education practice also in the following years. During his research activities, he has published more than 200 publications of a book and journal nature published at home and abroad, which proves both his diligence and contribution to Kinanthropology.

His pedagogical and scientific work was also reflected in his professional growth in obtaining the rank of doctor of pedagogical sciences and subsequently in 1997 in his appointment as a professor in the field of Kinanthropology, in the creation and development of which he participated for a long time.

In addition to his pedagogical and scientific activities, Professor Rychtecký played a significant role in the direction of the faculty as a member of the faculty management in the position of vice-dean for science and vice-dean for external and international affairs, which he held at various stages of faculty development. He was also active in scientific societies and editorial boards of professional journals, among others he was the chairman of the Czech Kinanthropological Society and a long-time editor-in-chief of the journal Acta Universitatis Carolinae Kinanthropologica. Chairman of the Editorial Board of the journal Czech Kinanthropology and Chairman of the Olympic Academy. The professional community loses a significant and respected personality in him, but thanks to his lifelong efforts he has left a significant mark that goes beyond the scope of his life.

In prof. Rychtecký will be remembered permanently and with respect not only by his former colleagues, but also by several generations of graduates of the Faculty of Physical Education and Sports for his diligence, openness to both colleagues and students, willingness to discuss anything at any time, for his helpful attitude and willingness to cooperate and help even in the difficult situations that not only academic but also everyday life brought.

Honor his memory. 